\title{
Corrosion Inhibition of the Galvanic Couple Copper-Carbon Steel in Reverse Osmosis Water
}

\author{
Irene Carrillo, Benjamín Valdez, Roumen Zlatev, Margarita Stoycheva, Michael Schorr, \\ and Mónica Carrillo
}

Instituto de Ingeniería, Universidad Autónoma de Baja California, Boulevard, Benito Juárez y Calle a la Normal S/N, 2180 Mexicali, BCN, Mexico

Correspondence should be addressed to Benjamín Valdez, benval@iing.mxl.uabc.mx

Received 9 March 2011; Revised 24 May 2011; Accepted 24 May 2011

Academic Editor: Jerzy A. Szpunar

Copyright () 2011 Irene Carrillo et al. This is an open access article distributed under the Creative Commons Attribution License, which permits unrestricted use, distribution, and reproduction in any medium, provided the original work is properly cited.

\begin{abstract}
The purpose of this paper is to evaluate the electrochemical behaviour of corrosion inhibition of the copper-carbon steel galvanic couple (Cu-CS), exposed to reverse osmosis water $(\mathrm{RO})$ used for rinsing of heat exchangers for heavy duty machinery, during manufacture. Molybdate and nitrite salts were utilized to evaluate the inhibition behaviour under galvanic couple conditions. $\mathrm{Cu}-\mathrm{CS}$ couple was used as working electrodes to measure open circuit potential (OCP), potentiodynamic polarization (PP), and electrochemical impedance spectroscopy (EIS). The surface conditions were characterized by scanning electron microscopy (SEM) and electron dispersive X-ray spectroscopy (EDS). The most effective concentration ratio between molybdate and nitrite corrosion inhibitors was determined. The morphological study indicated molybdate deposition on the anodic sites of the galvanic couple. The design of molybdate-based corrosion inhibitor developed in the present work should be applied to control galvanic corrosion of the $\mathrm{Cu}-\mathrm{CS}$ couple during cleaning in the manufacture of heat exchangers.
\end{abstract}

\section{Introduction}

The study of inhibition mechanism, electrochemical, and kinetic behaviour of inorganic inhibitors such as molybdates and other salts applied to protect $\mathrm{Cu}-\mathrm{CS}$ galvanic couple in aqueous media, contributes to the prevention of corrosion, particularly in industrial equipment which inevitably requires joining pieces of different metals for its construction [1-6]. Heat exchangers are often constructed by dissimilar metals such as copper fins that cool the fluid by convection, internal copper tubes and carbon steel shells (Figure 1). The conditions of the cleaning process during the manufacture of heavy duty heat exchangers promote the dissolution of the anodic metal in a galvanic couple when it is rinsed with RO water, especially with an unfavourable cathode-anode area ratio of 2.4 to 1.0 .

The use molybdate-based corrosion inhibitors represents an environmentally friendly alternative, since sodium molybdate is considered a nontoxic inhibitor used for corrosion protection of cooling systems handling softened water. Sodium molybdate has a good performance as anodic inhibitor, that is incorporated into the metal surface forming a protective film. In combination with other chemical agents it may promote or inhibit the corrosion process. These results are directly dependent on the concentration, temperature, $\mathrm{pH}$, and the oxidizing agent. These studies have a relevant importance to find an efficient and economical solution to control the galvanic corrosion in industrial processes.

\section{Methodology}

2.1. Materials. Specimens of carbon steel UNS G10200 and copper UNS C10300 were used to prepare the galvanic couples. All the experiments were done with an area ratio 2.4 to 1.0 cathode-anode in order to simulate the real dimensions of heat exchangers for heavy machinery.

2.2. Specimen and Solutions Preparation. The working electrode was constructed joining metal coupons with a $\mathrm{Cu}$ area of $4.0 \mathrm{~cm}^{2}$ and $1.7 \mathrm{~cm}^{2}$ for CS, connected to an insulated 


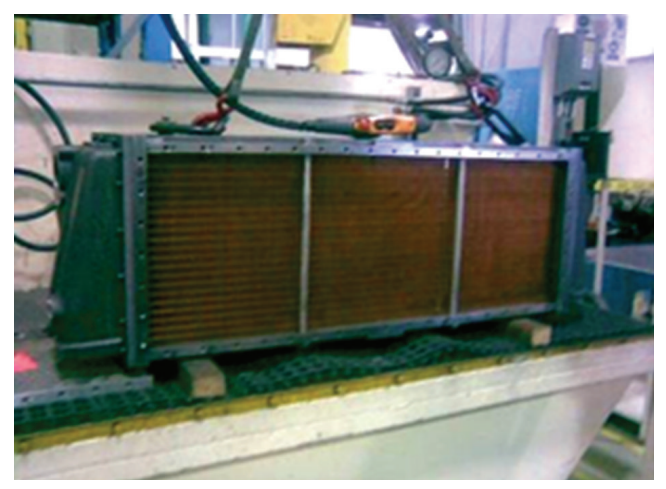

FIGURE 1: Heat exchanger for heavy duty machinery of copper UNS C10300 and carbon steel G10200.

$\mathrm{Cu}$ wire. The surfaces were sanded to 400 grit and rinsed with distilled water and acetone before coupling. The corrosive environment was $\mathrm{RO}$ water at $\mathrm{pH} 5.5$ and the applied temperature was $77^{\circ} \mathrm{C}$ to simulate the real rinse process conditions. The corrosion inhibitor solutions were prepared by adding the solid salts to the $\mathrm{RO}$ water: molybdate and nitrite.

2.3. Electrochemical Measurements. The OCP variation along time was recorded to analyze the effect of the sodium molybdate $\mathrm{Na}_{2} \mathrm{Mo}_{2} \mathrm{O}_{4}$ in different concentrations, adding sodium nitrite $\mathrm{NaNO}_{2}$ as oxidizing agent in $\mathrm{RO}$ water. The copper and steel coupons were separated by $7 \mathrm{~cm}$ and connected by an insulated $\mathrm{Cu}$ alligator clip which in turn connects to a multimeter Digital Protek Model B-45 to obtain a response in $\mathrm{mV}$.

Electrochemical polarization plots were produced using a three electrode cell: a Cu-CS working electrode, an $\mathrm{Ag} / \mathrm{AgCl}$ reference electrode and a high density graphite electrode as counter electrode. The potential-current plots were obtained as a function of sodium molybdate and sodium nitrite concentrations for each working electrode applying a scan rate of $5 \mathrm{mV} / \mathrm{s}$ in a potential range from -0.5 to $0.5 \mathrm{~V}$ versus. a $\mathrm{Ag} / \mathrm{AgCl}$ electrode.

In order to evaluate the mass transfer process and the film formed under molybdate effect, electrochemical impedance analysis were carried out after achieve the steady state potential, in the frequency range from $0.01 \mathrm{~Hz}$ to $10^{5} \mathrm{~Hz}$ with 10 points/decade. The Nyquist and Bode plots were obtained under potentiostatic conditions.

2.4. Morphology Analysis. Surface analyses of specimens tested in $\mathrm{RO}$ water inhibited with the most efficient formulations were performed without any previous treatment by scanning electron microscopy (SEM) and electron dispersive $\mathrm{X}$-ray spectroscopy (EDS). The model SEM used was Jeol JSM6360.

\section{Results and Discussion}

3.1. Open Circuit Potential Measurements. The OCP values with a potential shift to positive values in the presence of

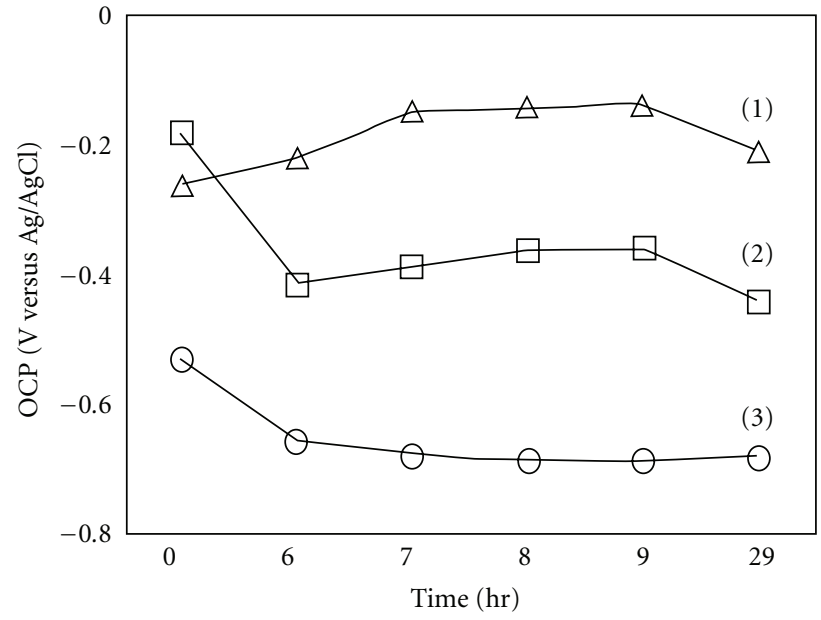

FIGURE 2: Variation of the open circuit potential with time: (1) $\mathrm{Na}_{2} \mathrm{MoO}_{4}: \mathrm{NaNO}_{2}$ 180:75 ppm; (2) $\mathrm{Na}_{2} \mathrm{MoO}_{4} 180 \mathrm{ppm}$; (3) RO water.

corrosion inhibitors obtained under different conditions for the galvanic couples tested are shown in Figure 2.

At the moment of immersion in $180 \mathrm{ppm} \mathrm{MoO}_{4}{ }^{2-}$ a potential of $-140 \mathrm{mV}$ was recorded. This potential moves fast toward negative values around $-400 \mathrm{mV}$ as a result of the breakdown of the molybdate layer formed on the steel surface. Simplistically, when iron corrodes, ions, in conjunction with other anions adsorb to form a nonprotective complex with $\mathrm{Fe}^{2+}$ ions $[3,7]$. The result is a soluble and shallow protective film due to the poor oxidation ability of $\mathrm{Na}_{2} \mathrm{MoO}_{4}$. Because of dissolved oxygen or other oxidizers in the water, some of the $\mathrm{Fe}^{2+}$ ions are oxidized to the ferric $\left(\mathrm{Fe}^{3+}\right)$ state, and the ferrous molybdate is transformed to ferric molybdate, which is both insoluble and protective in neutral and alkaline waters [3].

An OCP value of $-200 \mathrm{mV}$ was obtained when $\mathrm{NaNO}_{2}$ was added, due to its oxidant properties that improve the corrosion protection of CS.

3.2. Potentiodynamic Polarization. The effect of the ratio between the two inhibitors: $\mathrm{Na}_{2} \mathrm{MoO}_{4} ; \mathrm{NaNO}_{2}$, was studied by its electrochemical behaviour recording potentiodynamic polarization (PP) plots. The plots in Figure 3 were obtained in $\mathrm{RO}$ water at $77^{\circ} \mathrm{C}$ in the presence of the sodium molybdate; they clearly show a significant change in the displacement of the potential to electropositive values, implying a potential shift driven by kinetic changes in the cathodic process.

As the sodium molybdate concentration increases without sodium nitrite (Figure 3), the current density in the anodic curve tends to decrease and the performance inhibition process improves. Nevertheless, the inhibition only by sodium molybdate is not enough to avoid the corrosion damage of the CS in the short term due to the galvanic effect.

The addition of sodium nitrite improves the efficiency of the corrosion inhibition process. The presence of an oxide layer is essential for the corrosion inhibition action of 


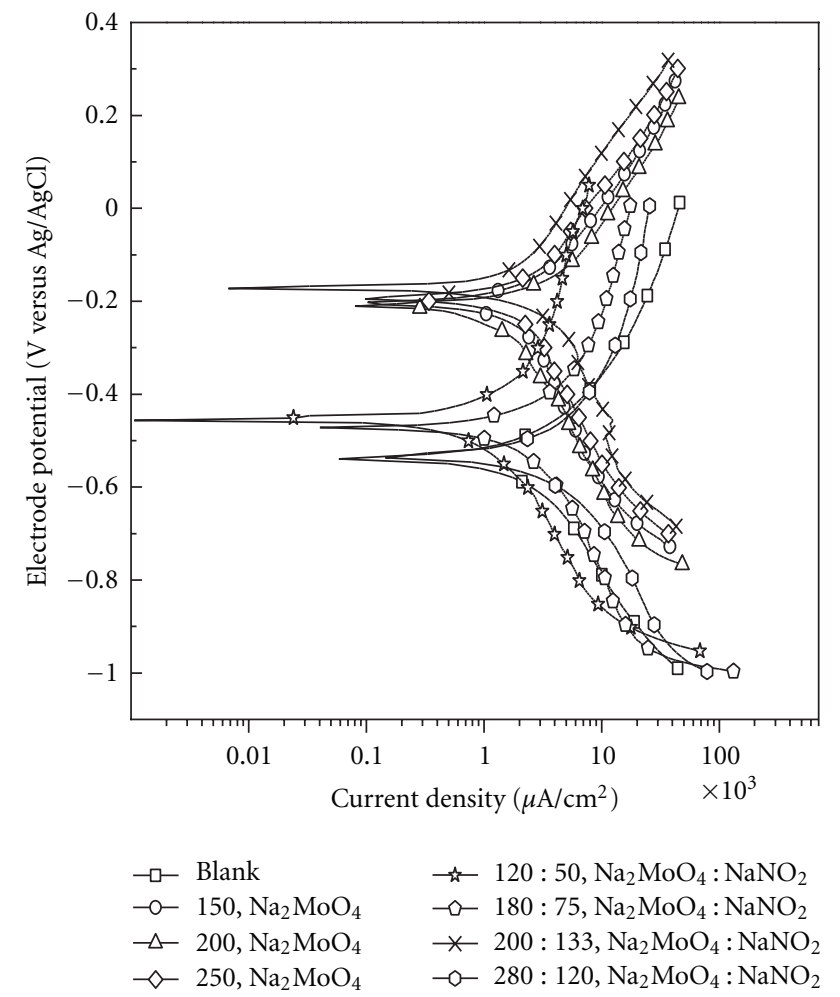

FIGURE 3: Current-Potential plots varying the concentration ratio $\mathrm{Na}_{2} \mathrm{MoO}_{4}: \mathrm{NaNO}_{2}$ in ppm.

TABLE 1: Current potential data varying the concentration ratio $\mathrm{Na}_{2} \mathrm{MoO}_{4}: \mathrm{NaNO}_{2}$.

\begin{tabular}{lcc}
\hline Concentration $(\mathrm{ppm})$ & Current $\left(\mu \mathrm{A} / \mathrm{cm}^{2}\right)$ & $E(\mathrm{mV})$ \\
\hline Blank & 9.85 & -534 \\
$150 \mathrm{MoO}_{4}{ }^{-2}$ & 4.21 & -208 \\
$200 \mathrm{MoO}_{4}{ }^{-2}$ & 4.25 & -211 \\
$250 \mathrm{MoO}_{4}^{-2}$ & 3.77 & -200 \\
$120: 150 \mathrm{MoO}_{4}{ }^{-2}: \mathrm{NO}_{2}{ }^{-}$ & 2.52 & -454 \\
$180: 75 \mathrm{MoO}_{4}^{-2}: \mathrm{NO}_{2}{ }^{-}$ & 5.54 & -470 \\
$200: 133 \mathrm{MoO}_{4}^{-2}: \mathrm{NO}_{2}{ }^{-}$ & 2.33 & -167 \\
$280: 120 \mathrm{MoO}_{4}{ }^{-2}: \mathrm{NO}_{2}{ }^{-}$ & 3.81 & -475 \\
\hline
\end{tabular}

molybdate [3, 7-9] and in order to accelerate and stabilize the oxidized surface an oxidizing compound such as sodium nitrite is necessary. Finally, it was noted that in all the cases, the potential shift to positive values and the current density decreases, due to the electrostatic attraction force between the $\mathrm{MoO}_{4}{ }^{2-}$ anions and the metal electrons and its oxide promoting the formation of a polyoxomolybdate protective layer $[3,7,10]$. Since nitrite and dissolved oxygen (DO) or other anions seem to promote competitive adsorption over the anodic surface, the molybdate and nitrite ratio is very important to find the most efficient and economical solution.

The current and potential values of Table 1 were calculated from potentiodynamic tests by the Tafel polarization. The results of the corrosion rates are showed in Figure 4. The results showed that the best inhibitor concentration ratio was

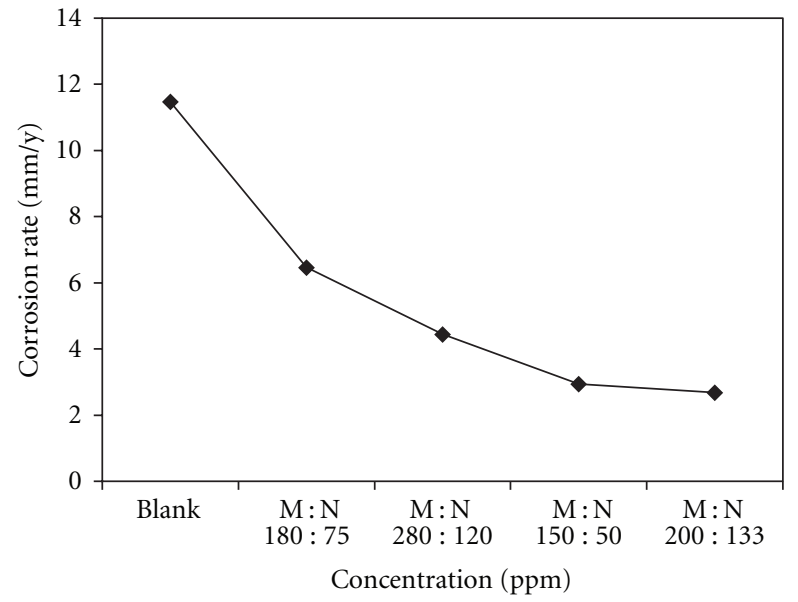

Figure 4: Corrosion rates of $\mathrm{Cu}-\mathrm{CS}$ as a function of $\mathrm{MoO}_{4}: \mathrm{NO}_{2}$ $(\mathrm{M}: \mathrm{N})$ ratio concentration.

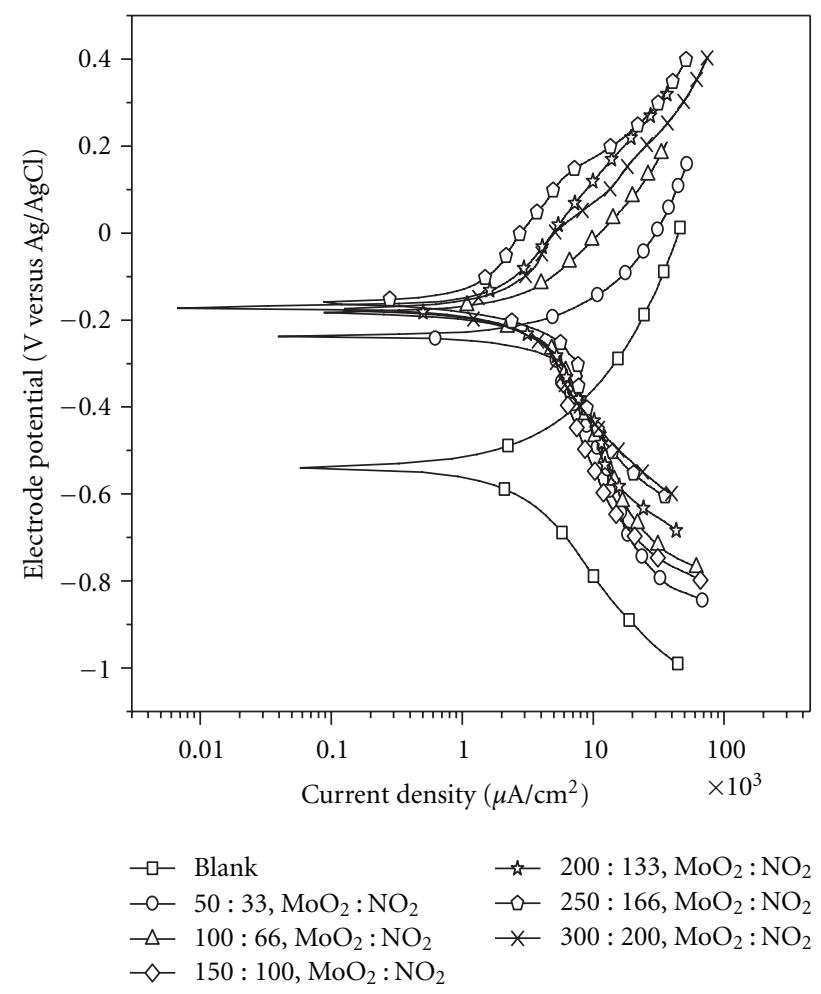

FIGURE 5: Current potential polarization plots for the $\mathrm{Cu}-\mathrm{CS}$ galvanic couple as a function of $\mathrm{Na}_{2} \mathrm{MoO}_{4}: \mathrm{NaNO}_{2}$ concentration, in a $1.5: 1$ ratio.

$200: 133 \mathrm{ppm} \mathrm{MoO}_{4}: \mathrm{NO}_{2}$. The electrochemical behaviour of the proportion 1.5 to 1 for $\mathrm{MoO}_{4}$ and $\mathrm{NO}_{2}$, respectively, was studied varying their concentration.

The effect of both compounds under this ratio concentration is shown in Figure 5, which reveals a continuous ennobling of the potential that drives an acceleration of the anodic reaction. Table 2 shows the potential and current values from Tafel polarization. On the other hand, the ratio $250-166$ ppm leads to a potential of -0.146 volts with a lower 
TABLE 2: Current potential data as a function of $\mathrm{Na}_{2} \mathrm{MoO}_{4}: \mathrm{NaNO}_{2}$ concentration in a $1.5: 1$ ratio.

\begin{tabular}{lcc}
\hline Concentration $(\mathrm{ppm})$ & Current $\left(\mu \mathrm{A} / \mathrm{cm}^{2}\right)$ & $E(\mathrm{mV})$ \\
\hline Blank & 9.85 & -534 \\
$50: 33 \mathrm{Na}_{2} \mathrm{MoO}_{4}{ }^{-2}: \mathrm{NO}_{2}{ }^{-}$ & 5.67 & -233 \\
$100: 66 \mathrm{Na}_{2} \mathrm{MoO}_{4}{ }^{-2}: \mathrm{NO}_{2}{ }^{-}$ & 2.85 & -180 \\
$150: 100 \mathrm{Na}_{2} \mathrm{MoO}_{4}{ }^{-2}: \mathrm{NO}_{2}{ }^{-}$ & 2.86 & -181 \\
$200: 100 \mathrm{Na}_{2} \mathrm{MoO}_{4}{ }^{-2}: \mathrm{NO}_{2}{ }^{-}$ & 2.68 & -177 \\
$250: 166 \mathrm{Na}_{2} \mathrm{MoO}_{4}{ }^{-2}: \mathrm{NO}_{2}{ }^{-}$ & 0.6 & -154 \\
$300: 200 \mathrm{Na}_{2} \mathrm{MoO}_{4}{ }^{-2}: \mathrm{NO}_{2}{ }^{-}$ & 3.04 & -185 \\
\hline
\end{tabular}

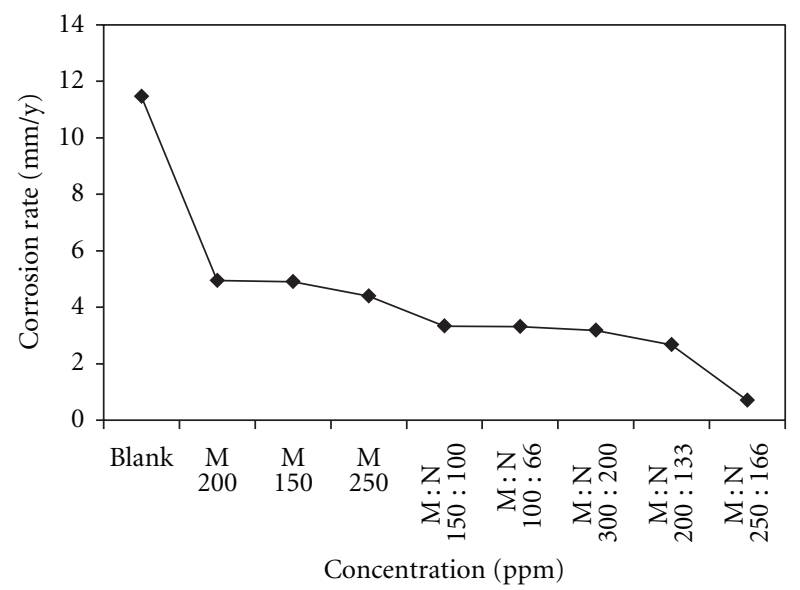

Figure 6: Corrosion rate of Cu-CS galvanic couple in function of the molybdate-nitrite ratio in $\mathrm{RO}$ water solutions.

current density that indicates the presence of CS corrosion protection.

When carbon steel corrodes, the $\mathrm{MoO}_{4}{ }^{-2}$ ions and other anions are fixed to the surface by adsorption to form a molybdate- $\mathrm{Fe}^{2+}$ complex, which sometimes is nonprotective because the ferrous compounds are soluble. Due to dissolved oxygen and another oxidants such as sodium nitrite in the $\mathrm{RO}$ water, the $\mathrm{Fe}^{2+}$ ions are oxidized to the ferric state $\left(\mathrm{Fe}^{3+}\right)$ and ferrous molybdate complex is transformed to ferric molybdate complex forming an insoluble and protective layer [3] in neutral, alkaline, and $\mathrm{RO}$ water.

Figure 6 shows a corrosion rate decrease up to a $94 \%$ of inhibition efficiency for the galvanic couple regarding the blank. The excess concentration of $\mathrm{Na}_{2} \mathrm{MoO}_{4}$ affects the inhibition process, given by the adsorption competitiveness of other anions.

The potentiodynamic polarization is an accelerated technique for corrosion measurements, therefore was possible to decrease the concentration inhibitors in real manufacture lines that involves cleaning process where the exposition time is short. The formulation $180-120 \mathrm{Na}_{2} \mathrm{MoO}_{4}: \mathrm{NaNO}_{2}$ was applied in a real industrial process and the corrosion inhibitors were added at the rinsing where the galvanic corrosion occurs during the heat exchanges cleaning process.

In Figure 7 it is possible to observe an application of these corrosion inhibitors combination. The surface appearance

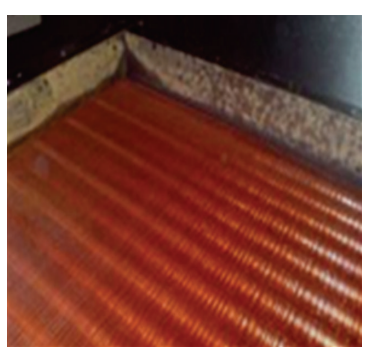

(a)

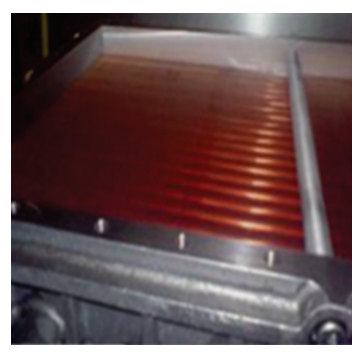

(b)
FIGURE 7: Heat exchangers manufacturing process. (a) without corrosion inhibitor in cleaning process. (b) Molybdate and nitrite were applied 180:120 ppm to inhibit galvanic corrosion.

of the heat exchanger after the cleaning process adding corrosion inhibitors is really good.

3.3. Electrochemical Impedance Spectroscopy. Electrochemical impedance spectroscopy assays for the systems: blank, $180: 120$ and $250: 166 \mathrm{Na}_{2} \mathrm{MoO}_{4}: \mathrm{NaNO}_{2}$ were performed to confirm the inhibition process and study the electrochemical corrosion inhibition of molybdate.

An initial process of charge transfer was recorded in the Nyquist diagram (Figure 8) for the blank represented by the small semicircle of low impedance at high frequencies followed by a greater semicircle at medium frequencies, that dominate the process where the carbon steel loss electrons to reach an equilibrium potential with the copper. Finally diffusion at very low frequencies contributes to the rapid formation of a porous layer which was observed at the end of the test. It is very notable that mass transfer by diffusion controls the process for the systems containing $\mathrm{Na}_{2} \mathrm{MoO}_{4}$ and $\mathrm{NaNO}_{2}$ since medium frequencies, the projection of centres from the experimental data points is also characterized by the relatively large angle of tilt which sometimes reaches values close to $45^{\circ}$ and is feature of Warburg impedance.

At high frequencies a small charge transfer semicircle was recorded in these systems, attributed at the oxidizing species that promote the oxidation followed for a diffusion process due the adsorbed specie where a combination is adjusted between the double layer capacitance value represented by a constant phase element (CPE) and the transfer charge resistance value (Rct) when the molybdate concentration increases over the surface and the result is a stable layer formation of great charge transfer resistance. An equivalent circuit was proposed in order to analyze the Bode and Nyquist plot showed in Figure 9. The fit line of Figure 8 shows the accuracy of the proposed circuit. Table 3 shows the impedance data of this arrangement.

The adjustment of these data shows a capacitive behaviour, dominated by the CPE element and an increasing in the impedance at high frequencies due to the corrosion inhibition process. Every interface has one capacitance and a charger transfer resistance related at the ions migration, the oxidation process, and the oxide film, therefore the equivalent circuit is constituted by two parts: the first elements represent the solution resistance and the carbon 


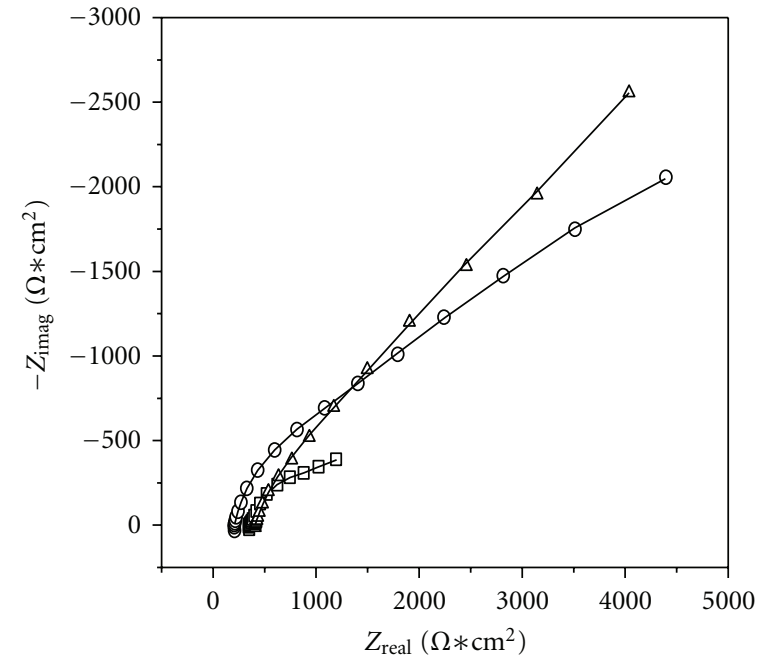

$\begin{array}{llll}\square & \text { Blank } & \triangle & 250: 166 \mathrm{MoO}_{4}: \mathrm{NO}_{2} \\ \circ & 180: 120 \mathrm{MoO}_{4}: \mathrm{NO}_{2} & \text { Fit }\end{array}$

(a)

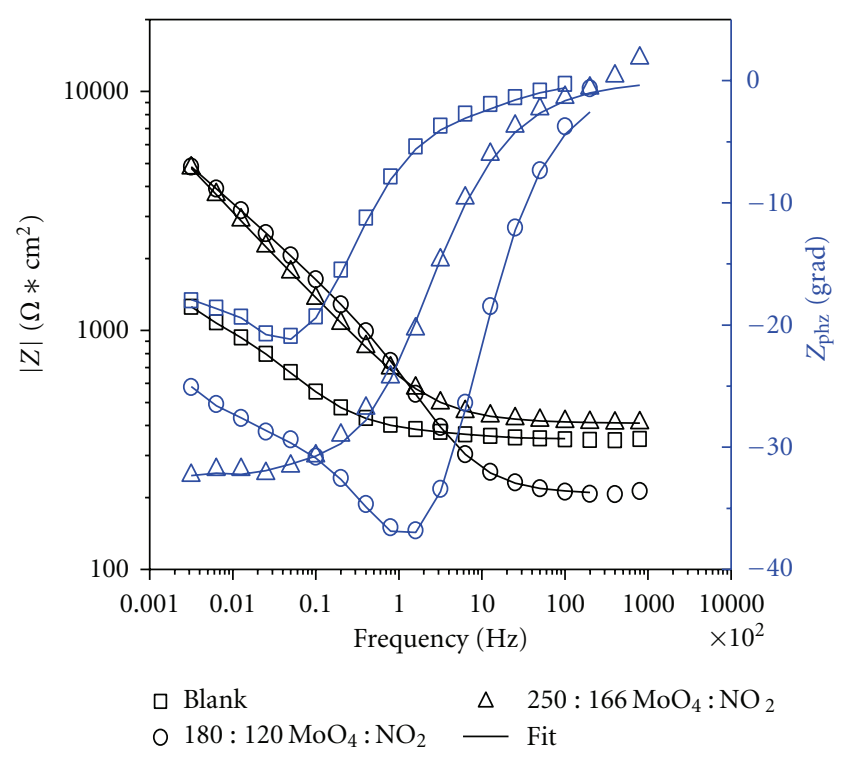

(b)

Figure 8: Nyquist and Bode diagram for $\mathrm{Cu}-\mathrm{CS}$ galvanic couple in RO water with molybdate sodium and nitrite sodium.

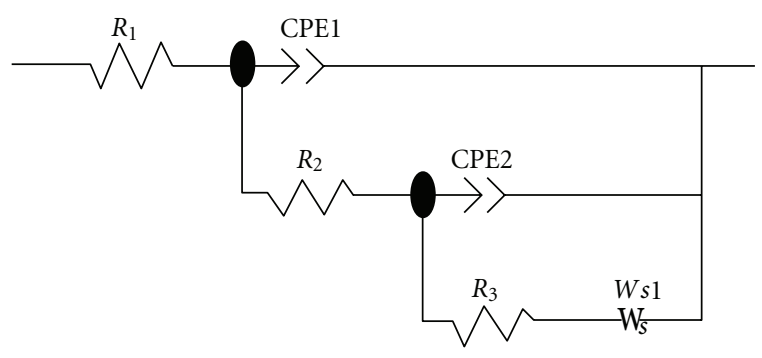

Figure 9: Electrical equivalent circuit proposed to simulate the impedance behaviour of $\mathrm{Cu}-\mathrm{CS}$ couple in $\mathrm{RO}$ water.

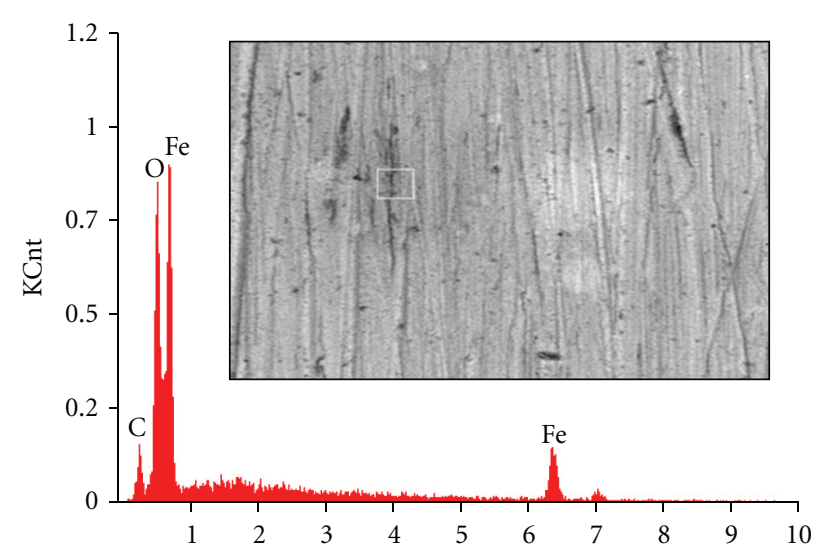

(a)

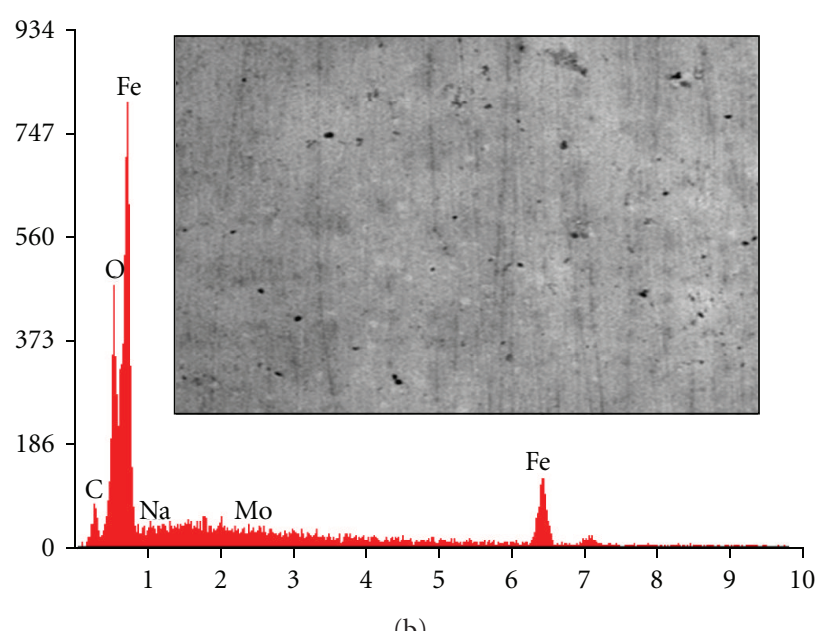

(b)

FIGURE 10: SEM and EDS for CS exposed to RO water without corrosion inhibitors.

steel surface portion in contact with the electrolyte and its respective polarization resistance increase under the effect of molybdate concentration increment and the oxidation of the $\mathrm{Fe}^{2+}$ to $\mathrm{Fe}^{3+}$ promoted by the nitrite and DO. The second part represents the double layer that contains the Rct element (R3) which increases significantly because the film is protecting $\mathrm{CS}$ and $\mathrm{Cu}$ remains stable; the subsequent studies of surface analysis by EDS show the molybdenum presence in the surface, nevertheless is not a uniform layer.

\section{Morphological Study}

The anodic surface was analyzed to evaluate the molybdate incorporated by adsorption to form a polyoxomolybdate ferric complex $[3,7,9]$ that protect the carbon steel even under galvanic conditions.

The microphotography in Figure 10(a) shows an oxide porous thick layer in the carbon steel surface that was in contact with $\mathrm{Cu}$. The porous of the iron oxide black layer was also observed visually The amount in weight recorded was of $87 \%$ wt iron and $8.9 \%$ wt oxygen. An area zoom of Figure 10(a) was done on a surface defect (b). High oxygen 
TABLe 3: Parameters obtained from the fitting process with the equivalent circuit in Figure 9.

\begin{tabular}{lccccccccc}
\hline$\left[\mathrm{Na}_{2} \mathrm{Mo}_{4}\right](\mathrm{Ppm})$ & {$\left[\mathrm{NaNO}_{2}\right](\mathrm{Ppm})$} & $R_{1}\left(\Omega \cdot \mathrm{cm}^{2}\right)$ & $R_{2}\left(\Omega \cdot \mathrm{cm}^{2}\right)$ & $\mathrm{Y}_{2}, \mathrm{~s}$ & $N$ & $R_{3}\left(\Omega \cdot \mathrm{cm}^{2}\right)$ & $\mathrm{Y}_{2}, s$ & $n$ \\
\hline- & - & 351.7 & 38 & $1.89 \mathrm{e}-5$ & 0.86 & 676.2 & $1.46 \mathrm{e}-4$ & 0.72 & 1.679 \\
180 & 120 & 207.2 & 908.9 & $7.45 \mathrm{e}-6$ & 0.81 & 8341 & $1.16 \mathrm{e}-4$ & 0.47 & 0.800 \\
\hline
\end{tabular}

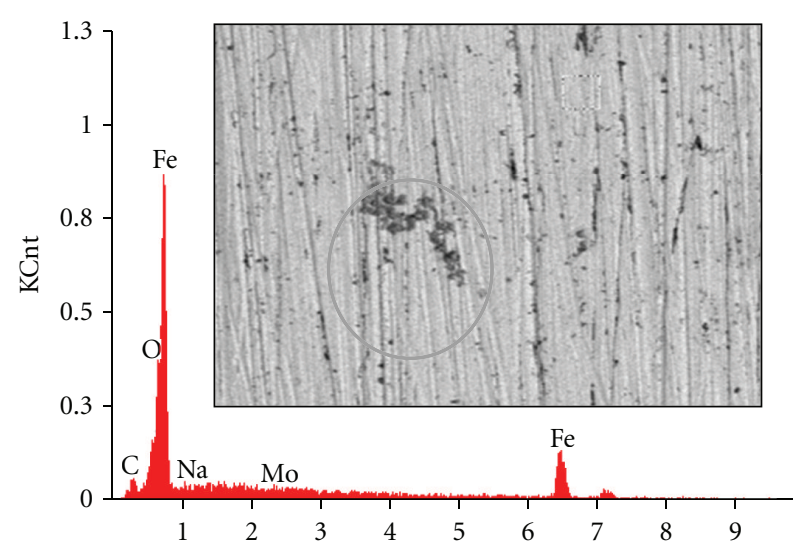

(a)

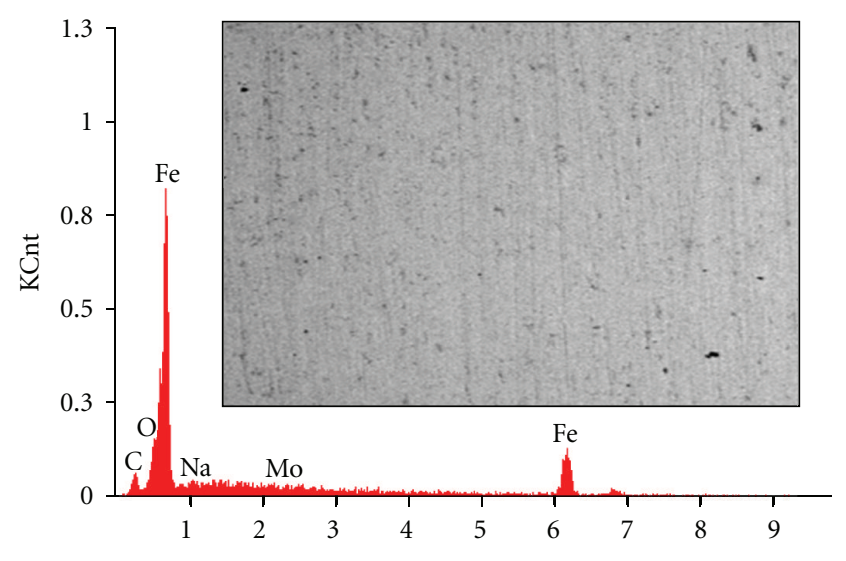

(b)

FIGURE 11: SEM and EDS of carbon steel under galvanic conditions in inhibited RO water by $180: 120 \mathrm{Na}_{2} \mathrm{MoO}_{4}$ and $\mathrm{NaNO}_{2}$.

contents (14\% wt) and a decreasing of Fe composition ( $80 \% \mathrm{wt}$ ) was recorded by EDS test as consequence of the galvanic corrosion and the precipitation by soluble compounds formation.

The film deposited on CS surface was characterized by EDS and is shown in Figure 11. The EDS test Figure 11(a) recorded small amounts of molybdenum (0.26-0.45\% weight) by a reduction reaction of $\mathrm{MoO}_{4}{ }^{2-}$ anion to join it with the ferric oxide layer [1, 3, 6-8]. The homogeneous surface improves with the molybdate concentration increment. There was a $30 \%$ decreasing of oxygen with respect to the blank and the Fe content is above $92 \%$. The area zoom Figure 11(b) $180: 120 \mathrm{ppm} \mathrm{Na} \mathrm{MoO}_{4}: \mathrm{NaNO}_{2}$ shows a small accumulation of molybdate in a surface defect which seems as "restorative effect". This behaviour was reported from alloy

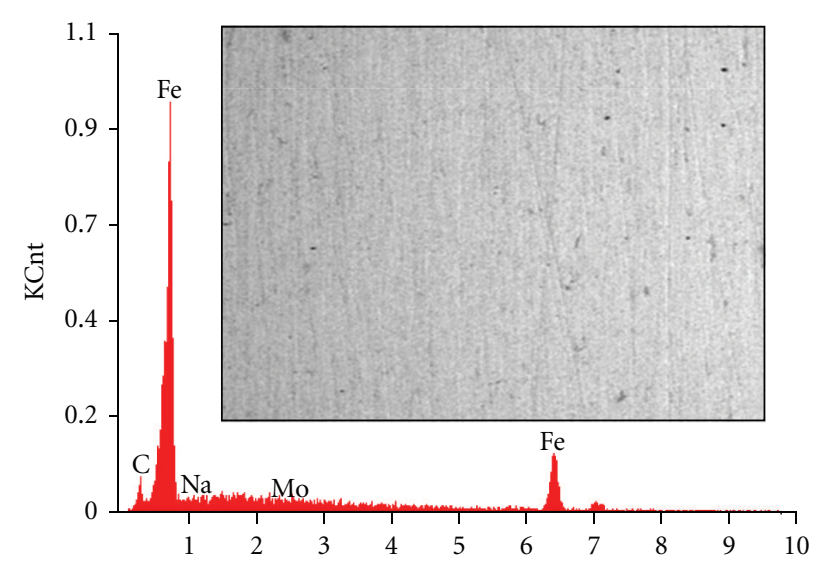

(a)

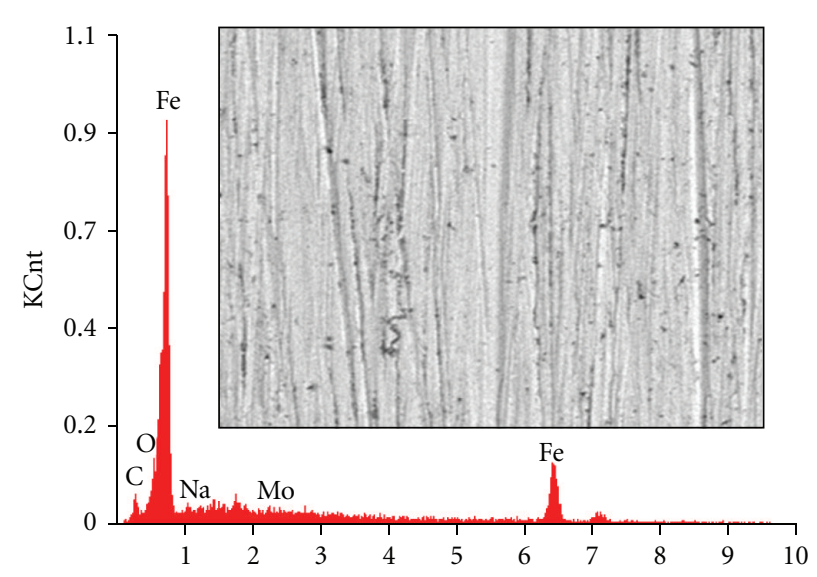

(b)

FIGURE 12: SEM and EDS of carbon steel under galvanic conditions in inhibited RO water by $250: 166 \mathrm{Na}_{2} \mathrm{MoO}_{4}$ and $\mathrm{NaNO}_{2}$.

with molybdenum can repair the defect of the iron passive in borate buffer solution and inhibit pit growth [11].

It is possible to observe in low quantity the same behaviour in a zoom area of part Figure 12(b) $250: 166 \mathrm{ppm}$ $\mathrm{Na}_{2} \mathrm{MoO}_{4}: \mathrm{NaNO}_{2}$ when the surface has defects, no homogeneous zones or susceptible zones by copper contact, the adsorption of the $\mathrm{MoO}_{4}{ }^{2-}$ anions increases, taking account there is an electrostatic attraction between the Fe cations and the $\mathrm{MoO}_{4}{ }^{2-},[12,13]$ this is deposited in the anodic zones $(0.45-0.90 \%)$, the most susceptible area portions in contact with the copper and the solution.

The electrochemical tests showed the effect by increasing the concentration of sodium molybdate (limited to $250 \mathrm{ppm}$ in combination with the sodium nitrite) $[6,8,14,15]$ to decrease the corrosion rate and the results by EDS confirm 
a deposition of molybdenum compounds joined to the oxide layer and oxide reduction in all the cases. The combination $250: 166 \mathrm{MoO}_{4}: \mathrm{NO}_{2}$ was totally confirmed as the optimal formulation for copper and carbon galvanic couple.

\section{Conclusions}

Good performance of the corrosion inhibitor requires the polyoxomolybdate complex layer formation which is more stable, highly protective and a great charge transfer with ferric compounds, necessary to ensure the oxidation of $\mathrm{Fe}^{2+}$ to $\mathrm{Fe}^{3+}$ promoted by the nitrite. The optimal inhibitor concentration was $250 \mathrm{ppm}$ of sodium molybdate and $166 \mathrm{ppm}$ of sodium nitrite obtaining $94 \%$ inhibition efficiency. The economical application for the heat exchanger cleaning was 180 : 120 molybdate: nitrite and it takes 24 minutes. Molybdate excess concentration affects the inhibition related to the nitrite and DO molecules and possible other anions which promote the adsorption competitiveness influenced by the concentration ratio between molybdate and nitrite hence the importance of the efficient combination. The impedance test shows the diffusion control for the formation of resistant molybdate film. Molybdate can be physically adsorbed on the metal surface or on the hydroxide layer available on the surface and act in anodic zones by electrostatic attraction.

\section{Acknowledgments}

The authors thank Honeywell Thermal Systems of Mexicali, for support of the study development and to implement the corrosion inhibitor in their cleaning process for heat exchangers during the manufacture. Thanks are also due to CONACYT for the Scholarship 208739 support to I. Carrillo.

\section{References}

[1] C. M. Mustafa and S. M. S. I. Dulal, "Molybdate and nitrite as corrosion Iinhibitors for copper-coupled steel in simulated cooling water," Corrosion, vol. 52, no. 1, pp. 16-22, 1996.

[2] E. J. Talbot and D. R. Talbot, Corrosion Science and Technology, CRC Press, New York, NY, USA, 2007.

[3] J. R. Davis, "Corrosion fundamentals, testing and protection," ASM International and The materials Information Society, Ohio, EE.UU, 2000, http://www.asm.intl.org/.

[4] R. Francis, "Galvanic corrosion of high alloy stainless steels in sea water," British Corrosion Journal, vol. 29, no. 1, pp. 53-57, 1994.

[5] P. R. Roberge, Corrosion Engineering: Principles and Practice, McGraw-Hill, New York, NY, USA, 2008.

[6] I. Carrillo, Inhibition of the corrosion in galvanic couples copper and carbon steel of Heat Exchangers for heavy machinery industry, M.S. thesis, Instituto de Ingenieria de la Universidad Autonoma de Baja California for Engineering Master Degree, 2009.

[7] M. R. Ali, C. M. Mustafa, and M. Habib, "Effect of molybdate, nitrite, zinc ions on the corrosion inhibition of Mild steel in aqueous chloride media containing cupric ions," Journal of Scientific Research, vol. 1, pp. 82-91, 2009.

[8] M. Saremi, C. Dehghanian, and M. M. Sabet, "The effect of molybdate concentration and hydrodynamic effect on mild steel corrosion inhibition in simulated cooling water," Corrosion Science, vol. 48, no. 6, pp. 1404-1412, 2006.

[9] V. S. Sastri, Corrosion Inhibitors Principles and Applications, John Wiley \& Sons, Ontario, Canada, 1998.

[10] K. C. Emregül and A. A. Aksüt, "The effect of sodium molybdate on the pitting corrosion of aluminum," Corrosion Science, vol. 45, no. 11, pp. 2415-2433, 2003.

[11] E. Fujioka, H. Nishihara, and K. Aramaki, "The inhibition of pit nucleation and growth on the passive surface of iron in a borate buffer solution containing Cl- by oxidizing inhibitors," Corrosion Science, vol. 38, no. 11, pp. 1915-1933, 1996.

[12] M. Shams and L. Wang, "Mechanism of corrosion inhibition by sodium molybdate," in Proceedings of the Material Testing Laboratory, Government of Abu Dhabi Water, vol. 5, pp. 181202, Electricity Department, Umm Al Nar Station, Abu Dhabi, UAE, 1996.

[13] M. Meziane, F. Kermiche, and C. Fiaud, "Effect of molybdate ions as corrosion inhibitors of iron in neutral aqueous solutions," British Corrosion Journal, vol. 33, no. 4, pp. 302308, 1998.

[14] D. G. Kolman and S. R. Taylor, "Sodium molybdate as a corrosion inhibitor of mild steel in natural waters part 2 : molybdate concentration effects," Corrosion, vol. 49, no. 8, pp. 635-643, 1993.

[15] D. G. Kolman and S. R. Taylor, "Sodium molybdate as a corrosion inhibitor of mild steel in natural waters. Part 1: flow rate effects," Corrosion, vol. 49, no. 8, pp. 622-634, 1993. 

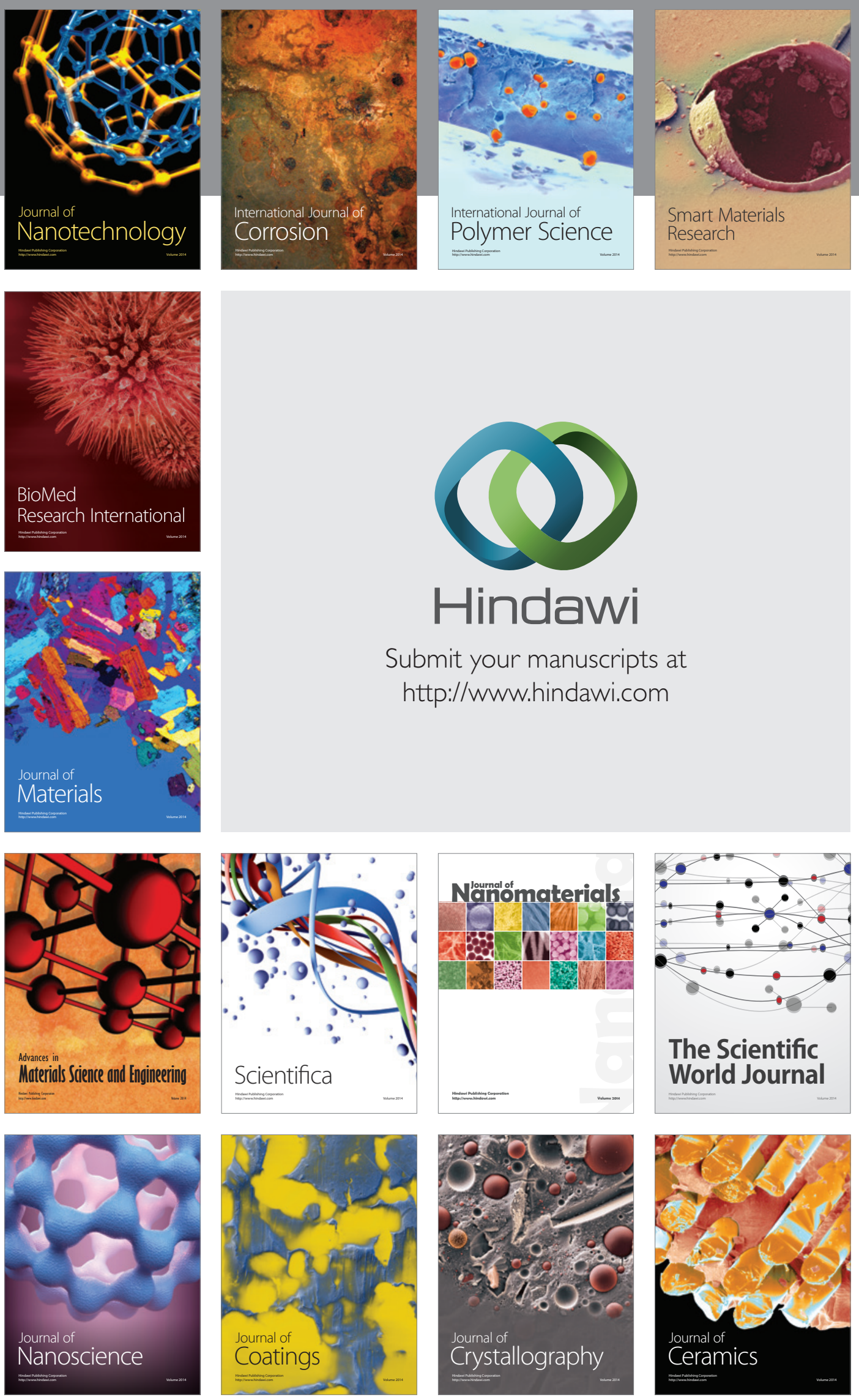

The Scientific World Journal

Submit your manuscripts at

http://www.hindawi.com

\section{World Journal}

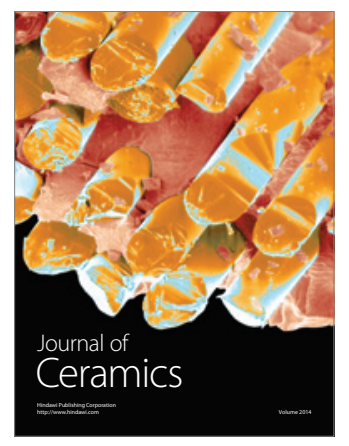

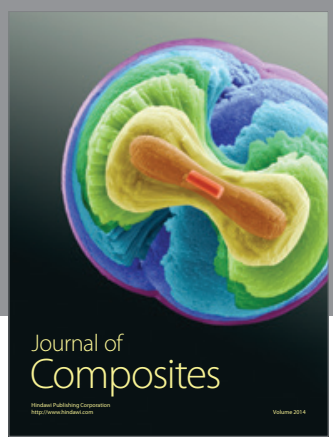
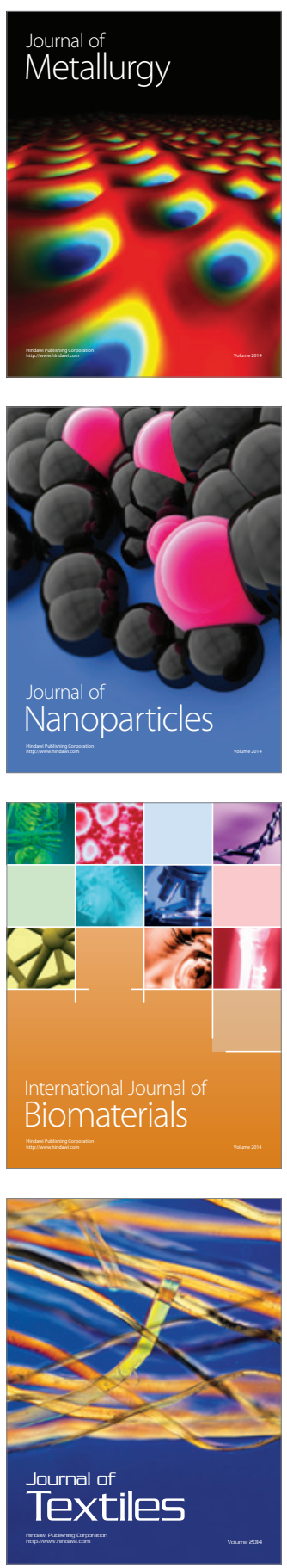